\title{
Constantin von Economo (1876-1931) and his legacy to neuroscience
}

\author{
Yasemin Kaya • Hilmi Uysal • Gokhan Akkoyunlu • \\ Levent Sarikcioglu
}

Received: 2 February 2015 / Accepted: 4 February 2015 / Published online: 24 February 2015

(C) Springer-Verlag Berlin Heidelberg 2015

Constantin von Economo was a Greek-born Austrian neurologist. He was an outstanding scientist of his time and made important contributions to our understanding on encephalitis lethargica, sleep regulation, and cytoarchitectonics of human cerebral cortex.

\section{His life}

Constantin von Economo was born on 21 August 1876 in Brăila, a city in eastern Romania $[5,8]$. He was the youngest child of an aristocratic Greek family. von Economo's family (Economo means "parish administrator" in Greek) had Austrian citizenship shortly before the First World War [9]. One

\footnotetext{
Y. Kaya $\cdot$ L. Sarikcioglu $(\bowtie)$

Department of Anatomy, Faculty of Medicine, Akdeniz University, 07070 Antalya, Turkey

e-mail: levent@akdeniz.edu.tr

L. Sarikcioglu

e-mail: sarikcioglul@gmail.com

Y. Kaya

e-mail: kayayasemin07@outlook.com

H. Uysal

Department of Neurology, Faculty of Medicine, Akdeniz University, 07070 Antalya, Turkey

e-mail: huysal@akdeniz.edu.tr

G. Akkoyunlu

Department of Histology and Embryology, Faculty of Medicine, Akdeniz University, 07070 Antalya, Turkey

e-mail: gokhan_akkoyunlu@hotmail.com
}

year after von Economo's birth, the family moved to Trieste. In 1893, von Economo moved to Vienna to study mechanical engineering and 2 years later, he decided to study medicine. During his education in medical school of University of Vienna, he worked in Histology and Physiology Institutes of the university. In 1901, he graduated from medical school and worked as a physician in Vienna Hospital Clinic for Internal Medicine [9]. After a 1-year period in that clinic, he spent some years in certain cities of Europe (Paris, Munich, Berlin, Nancy) to gather experience on neurology, psychiatry, and hypnosis under supervision of outstanding scientists such as Pierre Marie (1844-1910), Emil Kraepelin (1856-1926), Alois Alzheimer (1864-1915), and Hermann Oppenheim (1858-1919). In 1906, he came back to Vienna and became an assistant at the Clinic for Psychiatry and Nervous Diseases at Vienna's General Hospital. He was appointed as lecturer in 1913 and professor of Psychiatry and Neurology in 1921 at the Vienna University [9]. After coming back to Vienna, he spent the last 25 years of his life that was ended by a heart attack in 1931 .

\section{Encephalitis lethargica epidemica (von Economo encephalitis)}

Encephalitis lethargica is a neuropsychiatric disorder, and its first evidence was presented by von Economo in April 1917 to the Vienna Psychiatric Society. One month later, his article based on this presentation of encephalitis lethargica was published in the Wiener Klinische Wochenschrift [12]. In this article, he reported seven cases with encephalitis lethargica. The discovery of this new disease was not incidental since it was related to an influenza epidemic, so-called Spanish influenza epidemic. After the 1916-1917 epidemic, the disease 
disappeared in Vienna, but reports of similar cases were observed in France and England during 1918. The epidemic was widespread to the USA and became pandemia in Europe and North America in the early 1920s. Peak of the disease was observed in 1923; nearly 2000 deaths in the USA were noted [6].

Although he wrote several articles on Encephalitic lethargica, von Economo collected his observations in three monographs published in 1925 [15], 1929 [13], and 1931 [14]. He introduced a typology classifying it into full clinical spectrum (somnolent-ophthalmoplegic, hyperkinetic, and amyostatic-akinetic forms) [7]. He reported that majority of the Encephalitic lethargica cases were the patients aged 1545 years, third or fourth decades of life [14]. It was defined as a condition primarily involving prolonged somnolence and paralysis (particularly paralysis of the oculomotor nerve resulting ptosis) [3].

Von Economo wrote the following for description of one of his case:

Case 1: 31-year-old woman

The patient became sick on February 4, 1917, with shivering, headache, and somnolence. On February 26, she was somnolent and slept throughout the day, but it was possible to get her attention by calling her, and she answered in a normal manner; left to herself, she fell asleep again. Total paralysis of the external oculomotor nerve, both eyes being fixed with no movement in the outer angle. There was ptosis, sensitivity to pressure on the eyeballs, and a difference of reflexes on the right side, and her temperature was $36.2^{\circ} \mathrm{C}\left[97.1^{\circ} \mathrm{F}\right]$. Sleepiness increased to extreme stupor, accompanied by a complete paralysis of the right upper limb. Rigor of both lower limbs with Babinski's present. Temperature $36.8^{\circ} \mathrm{C}$ [98.2 $\left.{ }^{\circ} \mathrm{F}\right]$. Pulse 48. On March 24, the stupor continued. Temperature $39.5^{\circ} \mathrm{C}\left[103.1^{\circ} \mathrm{F}\right]$. Decubitus. No abnormalities of the internal viscera. From then on, there was a slow recovery. On April 4, fever and somnolence had disappeared. The paralysis of the oculomotor nerve began to disappear, as did the paralysis of the upper extremity. Babinski sign was negative. At the beginning of May, the paralysis of the oculomotor nerve had disappeared completely. Only a mild tendency to sleep continued until the end of May, making a total of 4 months in all, and even after that the patient slept surprising much. The patient showed a mild impairment of her mental functions but this state also improved until the end of June when she died of pneumonia. At the onset, the spinal puncture showed an increase in pressure but the clear cerebrospinal fluid (CSF) was free of microorganisms. The protein content was increased: 5.5. The Nonne-Apelt reaction was slightly positive, 43 elements. The Wasserman reaction in the blood and the
CSF was negative. The urine findings were normal. Lumbar puncture shortly before death showed normal findings [11]

\section{Cytoarchitecture of the nervous system (von Economo and Koskitas' parcellation scheme)}

von Economo and his co-author, Georg N. Koskinas (18851975), published their monumental atlas on cytoarchitectonics of human cerebral cortex Die Cytoarchitektonik der Hirnrinde des erwachsenen Menschen in 1925 [15]. Dr. von Economo has already been studying on cytoarchitectonics of the

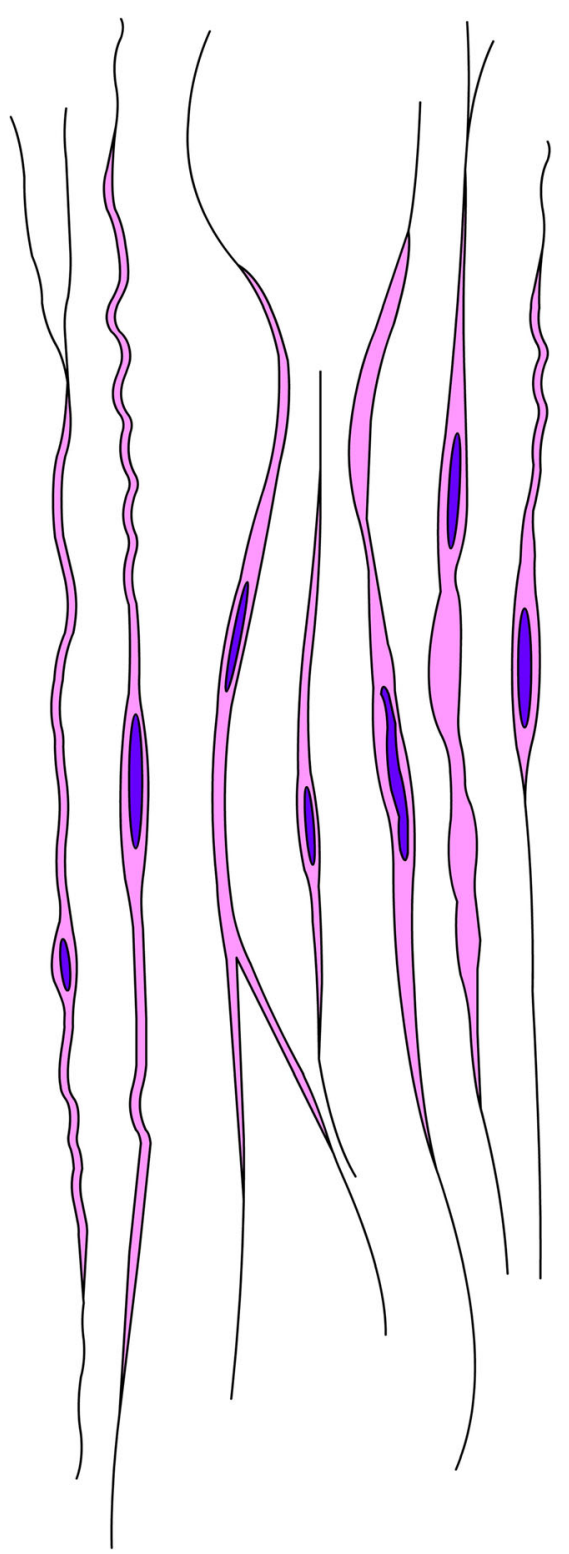

Fig.1 and cover figure von Economo neurons. Redrawn from von Economo's original study 
cerebral cortex since 1912 (Korbinian Brodmann published his monograph in 1909 [2]) and Dr. Koskinas joined him in 1919. von Economo and Koskinas divided the human cortex into seven lobes, which denoted by lobe's initials: frontal (F), superior limbic $(\mathrm{L})$, parietal $(\mathrm{P})$, temporal $(\mathrm{T})$, insular $(\mathrm{I})$, occipital (O), inferior limbic, or hippocampal $(\mathrm{H})$. They proposed 107 areas (35 frontal, 13 superior limbic, 6 insular, 18 parietal, 7 occipital, 14 temporal, and 14 inferior limbic or hippocampal areas) $[10,15]$. They sectioned the whole brain serially perpendicular to its fronto-occipital axis. Their sectioning technique enabled them to examine dome, edge, wall, and floor of each cortical gyrus [10]. Their parcellation scheme was not passed into general use in the scientific parlance [10].

In addition to the description of 107 cortical areas, von Economo and Koskinas described five types of layers in the cortex: agranular, frontal, parietal, polar, and granular types. They also proposed the term of "koniocortex" to denote granular type since its dusty appearance (Greek word konis means "dust") [9]. The first description of the distinct rod and corkscrew cells in the layer $\mathrm{V}$ of anterior cingulate and frontoinsular areas was also provided. We know such neurons as "von Economo neurons" [8] (Fig. 1 and cover figure). They are distinct from pyramidal cells and putatively involved roles in social behavior and mental diseases. They can easily be distinguished from pyramidal cells because they have only a single large basal dendrite and bipolar shape [1, 17]. von Economo neurons emerge mainly after birth and their adult number is attained by 4 years of age [1]. In all four living species of great apes and the humans, the von Economo neurons are more numerous in the right fronto-insular cortex and anterior cingulate cortex than the left. The von Economo neurons are about $6 \%$ more numerous in the right hemisphere in the neonate but about $30 \%$ more numerous in the adult $[1,16]$.

Existence of the von Economo neurons of the anterior cingulate cortex in all four living species of great apes and the humans implies that they evolved within the last 15 million years. However, their existence in the fronto-insular cortex was only reported in the great African apes, and not the orangutan, which implies their later emergence in that region ( 9 million years ago) $[1,16]$.

\section{Sleep and wakefulness center}

von Economo tried to find a distinct center for sleep and wakefulness. The topic of sleep in von Economo's researches is related to his work on encephalitis lethargic since in most ordinary forms of the encephalitis lethargica manifested with somnolence in combination with paralysis of the levator palpabrae superioris muscle, i.e., opthalmoplegia [8]. Based on his clinical observations from 1923 to 1925 , he assumed that "sleep-regulatory center (Schlafsteuerungszentrum)" is located near the oculomotor nucleus, the aqueduct of the third ventricle and the infundibular region, in the vicinity of other important vegetative centers regulating temperature, salt, and water metabolism. He noticed that this center should be located in the mesencephalic-diencephalic transitional [8]. Lesions in the anterior part (sleep part Schlafteil) cause insomnia; lesions in the posterior part (waking part Wachteil) induce sleep [8].

He was nominated for the 1926, 1930, and 1932 Nobel Prize in Physiology or Medicine for his work on encephalitis lethargic but did not receive the prize [10]. In 1976, von Economo was philatelically honored by the Austrian Government with a portrait stamp issued on the centennial of his birth [4]. He will be remembered by his contribution on the first description of the encephalitis lethargica, discovery of the von Economo neurons and his atlas of cytoarchitectonics of the cerebral cortex.

Acknowledgments The authors thank Akdeniz University Research Project Unit for their support.

Conflict of interest The authors declare no conflict of interest.

\section{References}

1. Allman JM, Watson KK, Tetreault NA, Hakeem AY (2005) Intuition and autism: a possible role for Von Economo neurons. Trends Cogn Sci 9:367-373. doi:10.1016/j.tics.2005.06.008

2. Brodmann K (1909) Vergleichende Lokalisationslehre der Großhirnrinde. J.A. Barth, Leipzig

3. Demetriades AK (2012) From encephalitis lethargica to cerebral cytoarchitectonics: the polymath talent of Constantin von Economo (1876-1931), pioneer neuroanatomist, neurophysiologist and military aviator. Scott Med J 57:232-236. doi:10.1258/smj.2012.012108

4. Haas LF (2002) Constantin von Economo (1876-1931). J Neurol Neurosurg Psychiatry 73:81

5. Pearce JM (1996) Baron Constantin von Economo and encephalitis lethargica. J Neurol Neurosurg Psychiatry 60:167

6. Reid AH, McCall S, Henry JM, Taubenberger JK (2001) Experimenting on the past: the enigma of von Economo's encephalitis lethargica. J Neuropathol Exp Neurol 60:663-670

7. Sak J, Grzybowski A (2013) Brain and aviation: on the 80th anniversary of Constantin von Economo's (1876-1931) death. Neurol Sci 34:387-391. doi:10.1007/s10072-012-1111-0

8. Triarhou LC (2006) The percipient observations of Constantin von Economo on encephalitis lethargica and sleep disruption and their lasting impact on contemporary sleep research. Brain Res Bull 69: 244-258. doi:10.1016/j.brainresbull.2006.02.002

9. Triarhou LC (2006) The signalling contributions of Constantin von Economo to basic, clinical and evolutionary neuroscience. Brain Res Bull 69:223-243. doi:10.1016/j.brainresbull.2006.02.001

10. Triarhou LC (2013) The cytoarchitectonic map of Constantin von Economo and Georg N. Koskinas. In: Geyer S, Turner R (eds) Microstructural parcellation of the human cerebral cortex. Springer, Berlin Heidelberg 
11. Vilensky J (2010) Encephalitis Lethargica the epidemic period. In: Vilensky J (ed) Encephalitis lethargica: during and after the epidemic. Oxford University Press, Oxford, pp 10-11

12. von Economo C (1917) Encephalitis lethargica. Wiener Klin Wochenschr 30:581-585

13. von Economo C (1929) Die encephalitis lethargica, ihre nachkrankheiten und ihre behandlung. Urban \& Schwarzenberg, Berlin-Wien

14. von Economo C (1931) Encephalitis lethargica: its sequelae and treatment. Oxford University Press, London
15. Von Economo C, Koskinas GN (1925) Die Cytoarchitektonik der Hirnrinde des erwachsenen Menschen. Atlas mit 112 mikrophotographischen Tafeln in besonderer Mappe. Verlag von Julius Springer, Wien

16. Watson KK (2006) The von Economo neurons: from cell to behavior. California Institute of Technology, Pasenada

17. Watson KK, Jones TK, Allman JM (2006) Dendritic architecture of the von Economo neurons. Neuroscience 141:1107-1112. doi:10. 1016/j.neuroscience.2006.04.084 